\title{
RESPONSE OF RAT CEREBRAL SOMATOSTATINERGIC SYSTEM TO A HIGH AMMONIA DIET
}

\author{
M. C. BOYANO-ADÁNEZ,' G. BODEGA ${ }^{2}$, V. BARRIOS ${ }^{3}$ and E. ARILLA ${ }^{1 *}$ \\ 'Unidad de Neuroendocrinología Molecular, Departamento de Bioquímica y Biología Molecular, \\ Facultad de Medicina, Universidad de Alcalá, E-28871 Alcalá de Henares, Madrid, Spain \\ ${ }^{2}$ Departamento de Biología Celular y Genética, Universidad de Alcalá, E-28871 Alcalá de Henares, \\ Madrid, Spain \\ ${ }^{3}$ Laboratorio de la Unidad de Crecimiento, Endocrinología y Metabolismo, Hospital Niño Jesús, \\ Universidad Autónoma, E-28009, Madrid, Spain
}

(Received 25 September 1995; accepted 5 March 1996)

\begin{abstract}
It has been reported that ingestion of an ammonium-containing diet produces hyperammonemia without encephalopathy, thus permitting the study of the specific effects of ammonia toxicity. The present study investigated the rat cerebral somatostatinergic system using this experimental model of hyperammonemia. Wistar rats were fed a high ammonia diet prepared by mixing a standard diet with ammonium acetate $(20 \% \mathrm{w} / \mathrm{w})$; in addition, $5 \mathrm{mM}$ of ammonium acetate was added to their water supply. Control rats were fed with a standard diet. The animals were sacrificed at 3, 7 and 15 days of ammonia ingestion. Ammonia levels in blood had increased $\approx 3$-fold at 7 days of ammonia ingestion. These changes were associated with a significant decrease in the specific binding of somatostatin (SS) to putative receptors sites in the frontoparietal cortex and hippocampus at 7 and 15 days after starting the high ammonia diet. Scatchard analysis shows that the decrease in SS binding resulted from a decrease in the number of available SS receptors rather than a change in receptor affinity. No changes in the somatostatin-like immunoreactivity content (SSLI) were detected in either brain area at the three study times. These results suggest that hyperammonemia alone can affect the rat brain somatostatinergic system. However, the animal model of hyperammonemia used here is insufficient to produce encephalopathy despite the significant increase in serum ammonia. Copyright (C) 1996 Elsevier Science Ltd
\end{abstract}

\section{INTRODUCTION}

Previous studies on the consequences of hyperammonemia were carried out with experimental models in which the animals developed secondary effects which obscured the effects owing to hyperammonemia alone (Lee and Fisher, 1961; Prior and Visek, 1972). In spite of much research, the mechanism for the specific effects of ammonia toxicity has not been completely elucidated (Raabe and Lin, 1985). The group of Dr Grisolía developed a new animal model of hyperammonemia consisting of feeding a high ammonium acetate-containing $\operatorname{diet}(20 \% \mathrm{w} / \mathrm{w})$ (Azorín et al., 1989). In contrast with the other models of hyperammonemia (Lee and Fisher, 1961; Prior and Visek, 1972), this model does not produce encephalopathy and therefore permits the study of the specific effects of ammonia toxicity. Utilizing this experimental model, these authors suggested that

*To whom all correspondence should be addressed. ammonium toxicity could be mediated by glutamate receptors (Felipo et al., 1988; Azorin et al., 1989). Several studies have shown that glutamate can influence somatostatin (SS)-containing neurons (Terry et al., 1981; Benyassi et al., 1991; Patel et al., 1991; Ham et al., 1993; Rage et al., 1993), suggesting that hyperammonemia in the absence of encephalopathy could modify the brain somatostatinergic system. In addition, ammonia per se also interferes with many electrophysiological properties of neuronal tissue that are modulated by SS (Pittman and Siggins, 1981; Cooper and Plum, 1987; Inoue et al., 1988; Jacquin et al., 1988; Moore et al., 1988; Watson and Pittman, 1988; Twery and Gallagher, 1989; Wang et al., 1989; Szerb and Butterworth, 1992; Schweitzer et al., 1993). Since SS exerts its biological actions through its binding to specific receptors (Epelbaum, 1986), a study of SS receptors in rats fed the ammonium-containing diet would provide further insight into the response of the brain somatostatinergic system to hyperammonemia. 
As an initial approach to examining this possibility, we studied the binding of SS to synaptosomes from frontoparietal cortex and hippocampus of normal rats and rats fed a high ammonia diet. The somatostatinlike immunoreactivity (SSLI) concentration in these brain areas was also determined. The frontoparietal cortex and hippocampus were chosen for analysis both because its sensitivity to ammonia and because of its high concentration of SS and SS receptors (Pittman and Siggins, 1981; Inoue et al., 1988; Szerb and Butterworth, 1992).

\section{MATERIALS}

\section{Chemicals}

Synthetic Tyr ${ }^{\prime \prime}$-SS and SS tetradecapeptide were purchased from Universal Biologicals LTD (Cambridge, U.K.); bacitracin and bovine serum albumin (fraction V), from Sigma (St. Louis, MO); and carrier free $\mathrm{Na}\left[{ }^{125} \mathrm{I}\right.$ ] (IMS $300,100 \mathrm{mCi} / \mathrm{ml}$ ) from the Radiochemical Centre (Amersham, U.K.). The rabbit antibody used in the radioimmunoassay technique was purchased from the Radiochemical Centre (Amersham, U.K.). This antiserum was raised in rabbits against SS-14, conjugated to bovine serum albumin and is specific for SS, but since SS constitutes the Cterminal portions of both SS-25 and SS-28, the antiserum does not distinguish between these three forms.

\section{Experimental animals}

Wistar rats $(n=50)$, initially weighing approximately $220-250 \mathrm{~g}$ were fed ad libitum with a standard diet (UAR AO4, Panlab, Spain) (17\% protein) or standard diet mixed with ammonium acetate $(20 \%$ w/w) as described by Azorin et al. (1989). In the group of animals fed a high ammonia diet, ammonium acetate $(5 \mathrm{mM})$ was also added to the water supply. The animals were killed by decapitation at 3,7 and 15 days after starting treatment. The brains were removed and the frontoparietal cortex and hippocampus were rapidly dissected.

\section{Ammonia assays}

Blood samples for ammonia determinations were collected at the moment of decapitation; plasma was separated immediately and stored at $-70^{\circ} \mathrm{C}$. Blood ammonia level was determined with an Ammonia Kit (Sigma, St. Louis, MO).

Extraction of tissue and radioimmunoassay of somatostatin

Tyr" ${ }^{\prime \prime}$-SS was radio-iodinated by the chloramine$T$ method (Greenwood et al., 1963). The tracer was purified in a Sephadex G-25 coarse column $(1 \times 100$ $\mathrm{cm}$ ), which had been equilibrated with $0.1 \mathrm{M}$ acetic acid, containing bovine serum albumin $0.1 \%(\mathrm{~m} / \mathrm{v})$. Specific radioactivity of the tracer was about 600 $\mathrm{Ci} / \mathrm{mmol}$.

For measurements of immunoreactivity, the frontoparietal cortex and hippocampus were rapidly homogenized using a Brinkman polytron (setting 5, $30 \mathrm{~s})$, in $1 \mathrm{ml} 2 \mathrm{M}$ acetic acid. Extracts were boiled for $5 \mathrm{~min}$ in a water bath, chilled in ice and aliquots ( 100 $\mu \mathrm{l})$ were removed for determination of protein (Lowry (t al., 1951). Subsequently, homogenates were centrifuged at $15,000 \times g$ for $15 \mathrm{~min}$ at $4 \mathrm{C}$ and the supernatant was neutralized with $2 \mathrm{M} \mathrm{NaOH}$. Extracts were immediately stored at $-70 \mathrm{C}$ until assay. The level of immunoreactivity was determined in tissue extracts by a modified radioimmunoassay method (Patel and Reichlin, 1978), with a sensitivity limit of $10 \mathrm{pg} / \mathrm{ml}$. The possibility that substances present in the tissue extracts might interfere with antibody-antigen binding and give rise to erroneous results, was checked by performing serial dilutions of selected extracts in the assays and comparing the resulting changes in hormonal immunoreactivity with those of the diluted standards. In addition, known standard amounts of the hormone were added to varying amounts of the extracts and serial dilutions again assayed, in order to determine if this exogenously added hormonal immunoreactivity could be measured reliably in the presence of tissue extracts. Incubation tubes, prepared in duplicate, contained $100 \mu \mathrm{l}$ samples of unknown or standard solutions of $0-500 \mathrm{pg}$ cyclic SS tetradecapeptide. diluted in phosphate buffer $(0.05 \mathrm{M}, \mathrm{pH} 7.2)$ containing $0.3 \%$ bovine serum albumin, $0.01 \mathrm{M}$ ethylene diamine tetra acetic acid [EDTA]), $200 \mu \mathrm{l}$ appropriately diluted anti-SS serum, $100 \mu \mathrm{l}$ freshly prepared $\left[{ }^{125} \mathrm{I}\right] \mathrm{Tyr}^{11}-\mathrm{SS}$, diluted in buffer to give $6000 \mathrm{cpm}$ (equivalent to $5-10 \mathrm{pg}$ ) and enough buffer to give a final volume of $0.8 \mathrm{ml}$. All reagents, as well as the assay tubes, were kept chilled in ice before incubation at $4 \mathrm{C}$ for $48 \mathrm{~h}$. Separation of bound and free hormone was accomplished by addition of $1 \mathrm{ml}$ dextran-coated charcoal (dextran: $0.2 \% \mathrm{w} / \mathrm{v}$, Serva, Feinbiochemica. Heidelberg, Germany). Dilution curves for each brain area were parallel to the standard curve. The coefficients for intra- and inter-assay variation were $6.5 \%$ and $8.3 \%$ respectively.

\section{Binding assay}

Synaptosomes from frontoparietal cortex and hippocampus were prepared as previously described $(\mathrm{Yu}$ and Ho, 1990). Experimental conditions for the binding of SS were essentially as described previously for 
this laboratory (Colás et al., 1990). Briefly, synaptosomes from frontoparietal cortex and hippocampus were separately incubated in $0.5 \mathrm{ml}$ of 50 $\mathrm{mM}$ Tris- $\mathrm{HCl}$ buffer (pH 7.5) containing $5 \mathrm{mM}$ $\mathrm{MgCl}_{2}, 30 \mathrm{mM} \mathrm{NaCl}, 1 \%$ bovine serum albumin, $0.1 \%$ bacitracin and $100 \mathrm{pM}$ of $\left[{ }^{125} \mathrm{I}\right] \mathrm{Tyr}{ }^{11}-\mathrm{SS}$, in the absence or presence of 0.01-100 nM unlabelled SS. After $60 \mathrm{~min}$ incubation at $25^{\circ} \mathrm{C}$, synaptosome-bound peptide was isolated by centrifugation at $13,000 \times g$ for $1.5 \mathrm{~min}$ and the radioactivity determined in a Kontron gamma counter. Non-specific binding was obtained from the amount of radioactivity bound in the presence of $10^{-6} \mathrm{M} \mathrm{SS}$ and represented about $20 \%$ of the binding observed in the absence of unlabelled peptide. This nonspecific component was subtracted from the total bound radioactivity in order to obtain the corresponding specific binding.

\section{Evaluation of degradation of radiolabelled peptide}

To determine the extent of degradation of radiolabelled peptide, we measured the ability of preincubated peptide to bind to fresh synaptosomes as previously described (Schonbrunn et al., 1983). Briefly, $\left.{ }^{125} \mathrm{I}\right]-\mathrm{Tyr}^{11}$-SS (100 pM) was incubated with synaptosomes from frontoparietal cortex and hippocampus of the rat $(1 \mathrm{mg}$ protein $/ \mathrm{ml})$ for $60 \mathrm{~min}$ at $25^{\circ} \mathrm{C}$. After this preincubation, aliquots of the medium were added to fresh synaptosomes and incubated for an additional $60 \mathrm{~min}$ at $25^{\circ} \mathrm{C}$. The fraction of the added radiolabelled peptide, which was specifically bound during the second incubation, was measured as previously described (Colás et al., 1990).

In a previous study of our group it was determined that freezing the brain membrane suspension at $-70 \mathrm{C}$ resulted in about $7 \%$ loss in specific binding of ${ }^{125} \mathrm{I}-\mathrm{Tyr}{ }^{11}$-SS after 1 month (Rodríguez-Sánchez et al., 1989).

\section{Data analysis}

The LIGAND computer program (Munson and Rodbard, 1980) was used to analyze the binding data. The use of this program allowed us to select those receptor models which best fit given sets of binding data. The same program was also used to present data in the form of Scatchard plots and to compute values for receptor affinity $\left(K_{\mathrm{d}}\right)$ and density $\left(B_{\max }\right)$ that best fit the sets of binding data for each rat. The paired $t$ test was applied to means derived from the best fit of data points for each individual animal.

\section{RESULTS}

As shown in Fig. 1, rats fed on ammonia did not gain as much weight as the animals on the standard

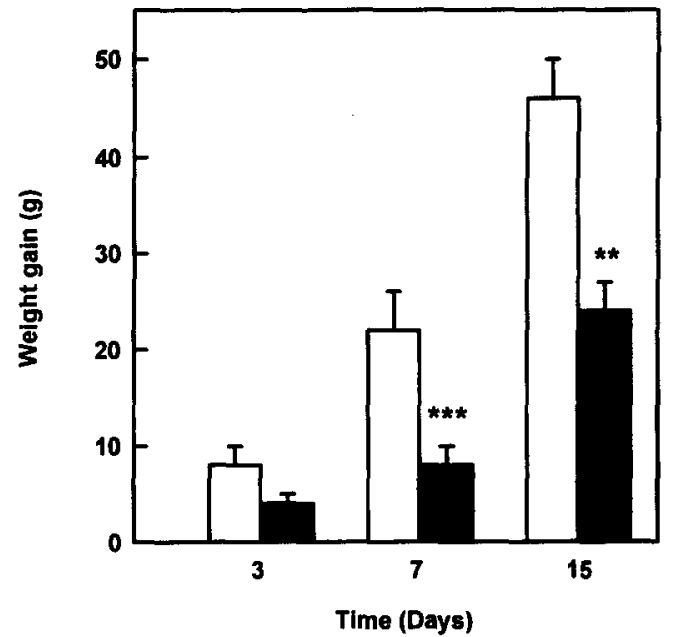

Fig. 1. Body weight of rats fed standard diet (open bars) or high ammonia diet (dotted bars) at 3,7, and 15 days from beginning the treatment. Each value is the mean \pm S.E.M. of five animals. From 7 days the body weights of rats fed ammonium diet were significantly lower $(* * P<0.01$; ${ }^{* * *} P<0.001$ ) than those fed a standard diet.

diet. Significant differences in weight were observed by the third day on the ammonia diet and were maintained for up to 15 days. Ammonia levels in blood increased from $0.13 \mathrm{mM}$ in control rats to $0.4 \mathrm{mM}$ in rats fed the high ammonia diet at 7 days of starting this diet. The high ammonia diet did not affect SSLI content in the two brain areas studied in comparison with the control groups (Table 1).

The specific binding of ${ }^{125} \mathrm{I}-\mathrm{Tyr}^{11}-\mathrm{SS}$ to frontoparietal cortex and hippocampus synaptosomes was time-dependent in all the experimental groups; an apparent equilibrium was reached and maintained between 50 and $120 \mathrm{~min}$ at $25^{\circ} \mathrm{C}$ (data not shown). All subsequent binding experiments were therefore conducted at $25^{\circ} \mathrm{C}$ for $60 \mathrm{~min}$. Degradation of peptide was determined in all the preparations to rule out the possibility of different degrading activities of SS which

Table 1. Effect of high ammonia diet on somatostatin-like immunoreactivity (SSLI) concentration in rat frontoparietal cortex and hippocampus

\begin{tabular}{lrcccc}
\hline & \multicolumn{2}{c}{ Frontoparietal cortex } & \multicolumn{2}{c}{ Hippocampus } \\
SSLI & \multicolumn{2}{c}{ SSLI } \\
Days & \multicolumn{1}{c}{ Control } & Ammonia & Control & Ammonia \\
\hline 3 & $11.04 \pm 3.26$ & $10.51 \pm 0.88$ & $12.20 \pm 2.80$ & $14.02 \pm 0.90$ \\
7 & $9.95 \pm 2.84$ & $10.56 \pm 1.20$ & $12.16 \pm 2.05$ & $11.75 \pm 0.26$ \\
15 & $10.93 \pm 1.31$ & $10.58 \pm 0.95$ & $12.85 \pm 0.92$ & $13.18 \pm 1.26$ \\
\hline
\end{tabular}

Determinations were made in duplicate for each experiment. Results are expressed as $\mathrm{ng}$ somatostatin (SS)/mg protein and as means \pm SEM for five rats in each group. No statistically significant differences were obtained when compared with control animals. 
might have affected the interpretation of the results. Frontoparietal cortical and hippocampal synaptosomes from all experimental groups showed a similar degradation of radiolabelled peptide capacity. and the values varied by no more than $10 \%$ in all groups. Increasing concentrations of unlabelled SS competitively inhibited the specific binding of ${ }^{125} I$ Tyr ${ }^{\prime \prime}$-SS to rat frontoparietal cortex and hippocampal synaptosome preparations in both control and high ammonia diet rats (Figs 2 and 3, left panels). The specific binding of the tracer to synaptosomes prepared from both brain areas was significantly lower in the rats fed ammonia than in those fed the standard diet at 7 and 15 days from the start of the treatment.

Scatchard plots of the binding data were linear. indicating the presence of a single class of receptors for the ligand (Figs 2 and 3, right panels). Table 2. which shows the corresponding equilibrium parameters for the SS receptors, indicates that at 7 and 15 days of high ammonia diet the number of SS receptors in synaptosomes from the frontoparietal cortex and hippocampus decreased without the affinity constant being affected. The Hill coefficient, calculated from competition curves, was close to unity (from -1.038 to -1.027 in hippocampus and from -1.041 to -1.027 in frontoparietal cortex). No significant differences were observed between the different time periods in both brain areas in terms of Hill coefficient.

We evaluated the in vitro effects of ammonium acetate on synaptosomes from frontoparietal cortex and hippocampus. The presence of ammonium acetate at variable concentrations $\left(10^{-11}-10^{-5} \mathrm{M}\right)$ in the incubation medium did not change the binding of SS to its receptors (data not shown).

\section{DISCUSSION}

The present results show that ingestion of an ammonium-containing diet as described by Azorín 't al. (1989) increases ammonia levels in blood and decreases the binding of SS to its specific receptors in rat frontoparietal cortex and hippocampus 7 and 15 days after commencing its ingestion. The effects of ammonium ingestion on growth patterns of rats and the ammonia levels in blood were no different from those obtained by Azorín et al. (1989). Similar concentrations of ammonia have been detected in the blood of patients with moderate hyperammonemia without any obvious neurological changes (Cooper and Plum, 1987). The decrease in the number of SS receptors in the frontoparietal cortex after 7 days of the high ammonia diet was greater than at day 15 and

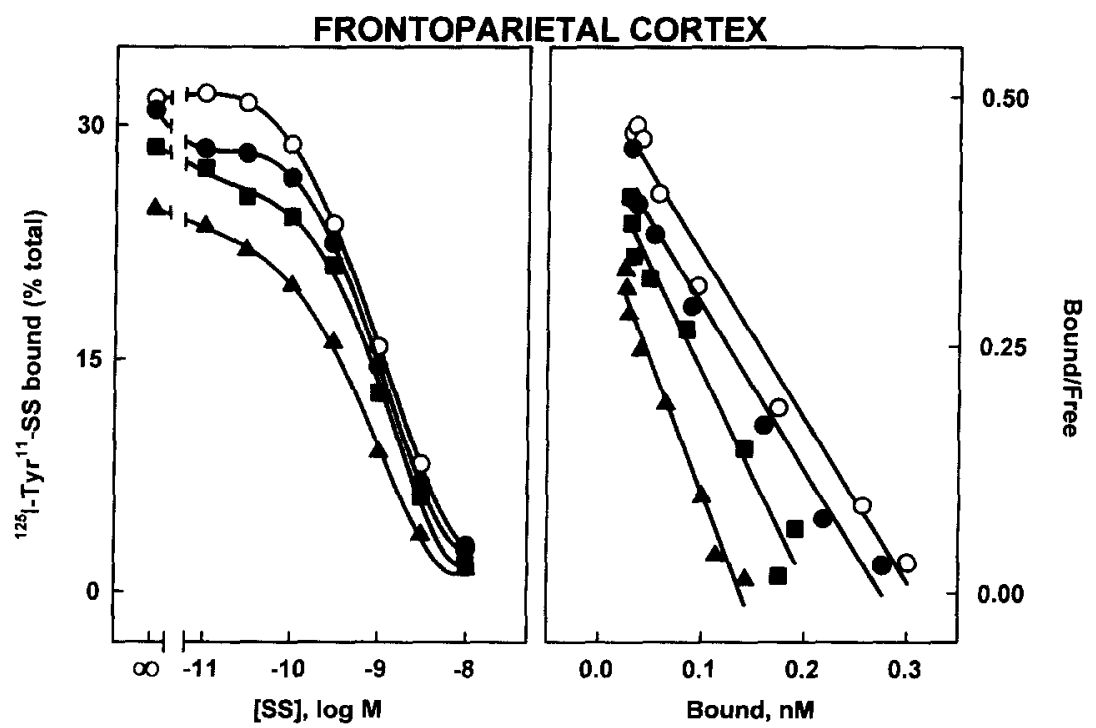

Fig. 2. Left panel: effect of high ammonia diet on competitive inhibition of specific ( $\left.{ }^{125} I-T y r^{\prime \prime}-S S, 100 \mathrm{pM}\right)$ binding to synaptosomes from the frontoparietal cortex. Synaptosomes ( $1 \mathrm{mg}$ protein/ml) were incubated for $60 \mathrm{~min}$ at $25 \mathrm{C}$ in the presence of $100 \mathrm{pM}^{125} \mathrm{I}-\mathrm{Tyr}^{11}-\mathrm{SS}$ and increasing concentrations of native peptide. Points correspond to values of animals fed standard diet $(O)$ or high ammonia diet at $3(\boldsymbol{O}), 7(\boldsymbol{A})$ and 15 ( $\boldsymbol{\square})$ days of the start of treatment. Each point is the mean of fivc replicate experiments. The results express the value of a pool of the control groups, since the $B_{\max }$ and the $K_{\mathrm{id}}$ values for the separate control groups were not affected. Right panel: Scatchard analysis of the same data. 


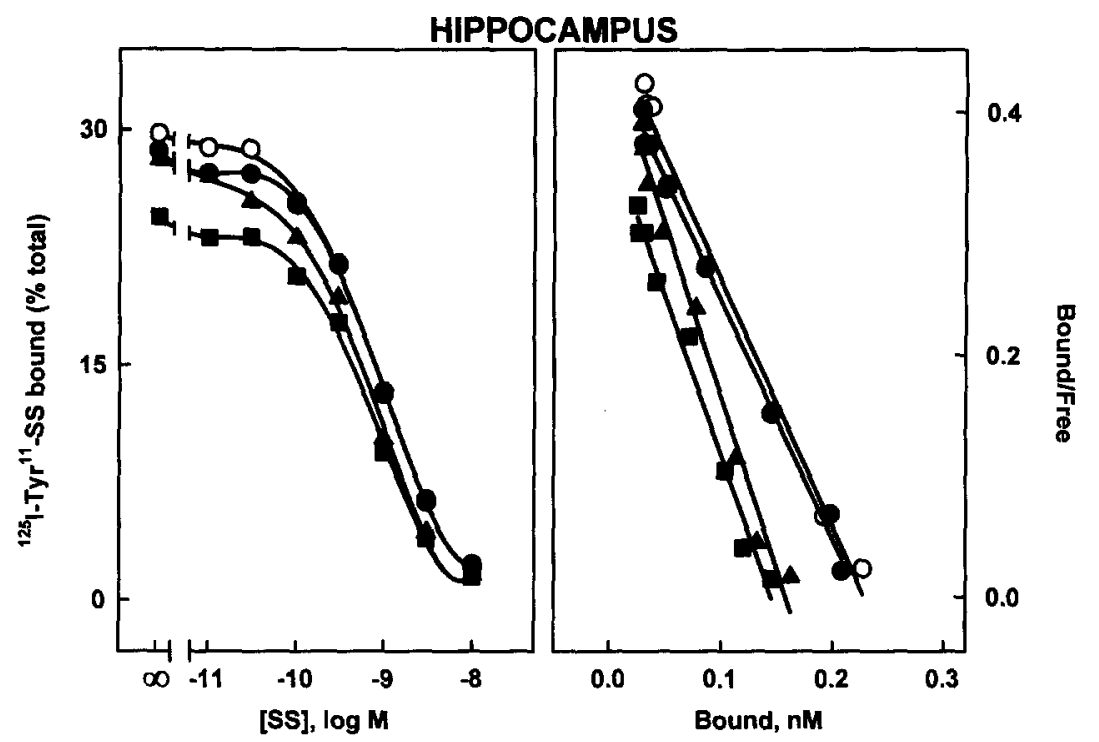

Fig. 3. Left panel: effect of high ammonia diet on competitive inhibition of specific ${ }^{125} \mathrm{I}-\mathrm{Ty} \mathrm{r}^{11}-\mathrm{SS}$ ( $\left.100 \mathrm{pM}\right)$ binding to synaptosomes from hippocampus. Synaptosomes $(1 \mathrm{mg}$ protein $/ \mathrm{ml})$ were incubated for $60 \mathrm{~min}$

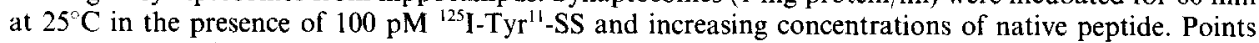
correspond to values of animals fed standard diet $(O)$ or high ammonia diet at $3(\boldsymbol{O}), 7(\boldsymbol{\Delta})$ and $15(\mathbf{D})$ days of the start of treatment. Each point is the mean of five replicate experiments. The results express the value of a pool of the control groups, since the $B_{\max }$ and the $K_{\mathrm{d}}$ values for the separate control groups were not affected. Right panel: Scatchard analysis of the same data.

greater than in the hippocampus which may be due to the higher blood ammonia levels reached at this time period.

For election of the tracer concentration, we based our study on the previous study of our group on characterization of somatostatin binding to synaptosomes from rat cerebral cortex (Colás et al., 1990) in which we observed that SS binding reached saturation with $100 \mathrm{pM}$ of ${ }^{125} \mathrm{I}_{-} \mathrm{Tyr}^{11}$-SS.

The SSLI content and the binding parameters of SS receptors in the frontoparietal cortex and hippocampus of the control rats were similar to those previously reported by others (Epelbaum et al., 1982; Pitkanen et al., 1986; Srikant and Patel, 1981). The Scatchard analysis of the stoichiometric data suggests the existence of only one type of SS receptor. This finding agrees with some studies in rat brain in which ${ }^{125} \mathrm{I}$-Tyr ${ }^{11}$-SS was also used as a tracer (Czernik and Petrack, 1983) but differs from other data reported when different SS analogs were used and two SS receptor subtypes were distinguished (Reubi, 1984; Tran et al., 1985). Recently, five different SS receptor subtypes have been cloned (Bell and Reisine, 1993) and the tissue distribution of the messenger ribonucleic acid for SS receptor subtypes has been studied in the rat (Bruno et al., 1993; Pérez et al., 1994). The fact that the studies with ${ }^{125} \mathrm{I}-\mathrm{Tyr}^{11}$-SS only show one single type of SS receptor might be explained by the hypothesis that the dissociation constants at which this radioligand binds to all types of SS receptors are virtually identical and cannot be discriminated by Scatchard analysis. The fact that the Hill coefficient was close to

Table 2. Effect of high ammonia diet on equilibrium parameters of somatostatin binding to synaptosomes from rat frontoparietal cortex and hippocampus

\begin{tabular}{lcccccccc}
\hline & \multicolumn{3}{c}{ Frontoparietal cortex } & \multicolumn{4}{c}{ Hippocampus } \\
Days & $\begin{array}{c}B_{\text {max }}, \text { fmol/mg protein } \\
\text { Control }\end{array}$ Ammonia & Control & Ammonia & Control & Ammonia & Amtrol & Control & Ammonia \\
\hline 3 & $325 \pm 15$ & $275 \pm 10$ & $0.65 \pm 0.04$ & $0.6 \pm 0.02$ & $221 \pm 15$ & $224 \pm 17$ & $0.53 \pm 0.09$ & $0.50 \pm 0.06$ \\
7 & $303 \pm 27$ & $138 \pm 21^{* *}$ & $0.55 \pm 0.05$ & $0.38 \pm 0.04$ & $231 \pm 17$ & $158 \pm 6^{*}$ & $0.41 \pm 0.07$ & $0.35 \pm 0.06$ \\
15 & $334 \pm 24$ & $206 \pm 15^{* *}$ & $0.67 \pm 0.04$ & $0.47 \pm 0.05$ & $215 \pm 12$ & $145 \pm 27^{*}$ & $0.43 \pm 0.09$ & $0.38 \pm 0.01$ \\
\hline
\end{tabular}

Results are expressed as means \pm SEM of five rats in each group. Binding parameters were calculated from Scatchard plots by linear regression. Student's $t$-test for unpaired variables was employed to assess differences between control and experimental groups. Statistical comparison versus control: $* P<0.05 ; * * P<0.01$. 
unity is in agreement with the heterogeneity of the SS receptors, as previously documented (Bruno $t^{\prime} t$ al. 1993: Pérez et al., 1994).

Felipo 't al. (1988) and Azorin 't al. (1989) have found that this experimental model of hyperammonemia affects glutamatergic neurotransmission. It has been demonstrated that glutamate exerts a stimulatory action on SS release involving $N$-methyl-D-aspartate (NMDA) receptor subtypes (Terry et al., 1981; Benyassi et al., 1991). In this regard, Dr Grisolia's group has also reported that ammonium leads to the activation of the NMDA type of glutamate receptor (Marcaida et al., 1992). Recently, Rage e' al. (1993) have shown that NMDA induces specific stimulation of SS gene expression and biosynthesis in vitro in several brain regions. Although SSLI content in the present study did not change in either brain area studied. this does not discount the possibility that glutamatergic neurotransmission could affect the SS-containing neurons. In this regard. no change in the SS content was detected in these brain regions after glutamate treatment by Terry ' $t$ al. (1981). An increase in the synthesizing activity of somatostatinergic neurons that did not exceed the amount required to compensate for the loss of SS owing to the increased release would be responsible for the lack of changes in SSLI content. The observation that SSLI levels are the same in high ammonia diet rats as in the controls does not exclude the possibility that synaptic SS concentrations may be increased after 7 days of ammonia ingestion since SS content reflects the balance between secretion, synthesis and storage. If this were the case, increased SS release or turnover might lead to down-regulation of SS receptors in both brain areas studied. A sustained increased occupancy of SS receptors which occurred secondary to modest increases in $\mathrm{SS}$ release rates might not be detected by measuring SS concentration. even thought it might be sufficient to initiate downregulation of SS receptors in this region. Further studies regarding precise synaptic events. including measurements of SS release rates are necessary.

The lack of effect of adding ammonium acetate to the incubation medium when measuring SS binding to synaptosomes from frontoparietal cortex and hippocampus suggests that high ammonia diet-induced effects on SS receptors in vivo do not represent a direct effect of ammonium acetate on the synaptosomes, and the effect of the diet may represent the beginning of a cellular response that is expressed as a change in membrane binding activity.

It has been suggested that the brain membrane lipid composition may change in response to ammonia
(Pappaset al., 1984). These findings together with the possibility that specific membrane phospholipids may participate in the modulation of SS binding to its receptor (Matozaki et al., 1987) have tempted speculation that these events could play a role in the decrease of the number of SS receptors found in the frontoparietal cortex and hippocampus coinciding with the significant elevation of ammonia levels in blood.

The lower food and caloric intake described in the present experimental model (Azorín et al., 1989) did not appear to affect the binding of SS to its specific receptors in the two studied brain areas since the body weight decreased throughout all the time studied. In addition, previous studies have shown that starvation decreases brain SSLI levels (Shulkes et al., 1983). Since this result does not agree with the observations in this study, which did not find any change in SSLI levels. it is possible that lower food and caloric intake was not a significant factor. Nevertheless, to our knowledge, the effect of starvation on brain SS receptors has not been demonstrated.

In relation to the specificity of the present results. reports on the effects of hyperammonemia on other brain peptides are very scarce. Hyperammonemia has been shown to increase serotonin $5-\mathrm{HT}_{1 \mathrm{~A}}$ receptor expression (Alexander et al., 1995). No appreciable change in the affinity or density of the high or low affinity GABA receptors, the density of glutamate receptors or the affinity of acetylcholine receptors has been observed in other studies (Ferenci et al., 1984). Zeneroli et al. (1985) have shown an increase in the number of opiate receptors in the frontal cortex and hypothalamus of dogs with portal-systemic encephalopathy. However, Ferenci ef al. (1984), in galactosamine-induced hepatic encephalopathy, found no appreciable changes in cerebral opiate receptors in rabbits.

Since SS hyperpolarizes neurons in cerebral cortex and hippocampus (Moore e't al., 1988; Watson and Pittman, 1988; Inoue et al., 1988; Jacquin et al., 1988; Twery and Gallagher, 1989: Wang et al., 1989), it is tempting to speculate that the decrease in the number of $\mathrm{SS}$ receptors seen in the present study could be, at least partly, responsible for the alterations that excess ammonia causes in the electrophysiological properties of neural tissue (Raabe and Lin, 1985; Cooper and Plum, 1987; Szerb and Butterworth, 1992).

Acknowledgements- The authors wish to thank C.F. Warren, from the Alcalá de Henares University Institute of Education Sciences for her assistance in the stylistic revision of the manuscript and Angela Martín-Espinosa for her 
invaluable technical assistance. This work was supported by Grants from the Alcalá de Henares University (001/96 and 008/96) DGICYT (PM95-0041) and FIS (94/0401) of Spain.

\section{REFERENCES}

Alexander J. J., Banerjee P., Dawson G. and Tonsgard J. H. (1995) Hyperammonemia increases serotonin 1A receptor expression in both rat hippocampus and a transfected hippocampal cell line. J. Neurosci. Res. 41, 105-110.

Azorin I., Miñana M. D., Felipo V. and Grisolía S. (1989) A simple animal model of hyperammonemia. Hepatology 10, 311-314.

Bell G. I. and Reisine T. (1993) Molecular biology of somatostatin receptors. Trends Neurosci. 16, 34-38.

Benyassi A., Tapia-Arancibia L. and Arancibia S. (1991) Glutamate peripherally administered exerts somatostatinreleasing action in the conscious rat. $J$. Neuroendocrinol. 3, 429-432.

Bruno J. F., Xu Y., Song J. and Berelowitz M. (1993) Tissue distribution of somatostatin receptor subtype messenger ribonucleic acid in the rat. Endocrinology 133, 2561-2567.

Colás B., Prieto J. C. and Arilla E. (1990) Somatostatin binding to dissociated cells from rat cerebral cortex. Peptides 11, 1109-1112.

Cooper A. L. and Plum F. (1987) Biochemistry and physiology of brain ammonia. Physiol. Rev. 67, 440-519.

Czernik A. J. and Petrack V. (1983) Somatostatin receptor binding in rat cerebral cortex. Characterization using a nonreducible somatostatin analog. J. Biol. Chem. 285, 5525-5530.

Epelbaum J. (1986) Somatostatin in the central nervous system: Physiology and pathological modifications. Prog. Neurobiol. 27, 63-100.

Epelbaum J., Tapia-Arancibia L., Kordon C. and Enjalbert A. (1982) Characterization, regional distribution and subcellular distribution of ${ }^{125} \mathrm{I}-\mathrm{Tyr}^{1}$-somatostatin binding sites in rat brain. $J$. Neurochem. 38, 1515-1523.

Felipo V., Miñana M. D., Azorin I. and Grisolía S. (1988) Induction of rat brain tubulin following ammonium ingestion. J. Neurochem. 51, 1041-1045.

Ferenci P., Pappas S. C., Munson P. J. and Jones E. A. (1984) Changes in the status of neurotransmitter receptors in a rabbit model of hepatic encephalopathy. Hepatology 4, 186-191.

Greenwood F. C., Hunter W. M. and Glober J. S. (1963) The preparation of ${ }^{131}$ I-labelled human growth hormone of high specific radioactivity. Biochem. J. 89, 114-123.

Ham J., Duberley R., Rickards C. and Scanlon M. F. (1993) Differential responses of rat cerebral somatostatinergic and cholinergic cells to glutamate agonists. $\mathrm{Mol}$. Chem. Neuropath. 19, 107-120.

Inoue M., Nakajima S. and Nakajima Y. (1988) Somatostatin induces an inward rectification in rat locus coeruleus neurones through a pertussis toxin-sensitive mechanism. J. Physiol. (London) 407, 177-198.

Jacquin T., Champagnat J., Madamba S. G., Denavit-Saubié M. and Siggins G. R. (1988) Somatostatin depresses excitability in neurons of the solitary tract complex through hyperpolarization and augmentation of $\mathrm{I}_{\mathrm{M}}$, a non-inactivating voltage-dependent outward current blocked by muscarinic agonists. Proc. Natl. Acad. Sci. USA 85, 948952.
Lee S. H. and Fisher B. (1961) Portacaval shunt in the rat. Surgery 50, 668-672.

Lowry O. H., Rosenbrough N. J., Farr A. L. and Randall R. J. (1951) Protein measurement with the Folin phenol reagent. J. Biol. Chem. 193, 265-275.

Marcaida G., Felipo V., Hermenegildo C., Miñana M. D. and Grisolía S. (1992) Acute ammonia toxicity is mediated by the NMDA type of glutamate receptors. Fedn Eur. Biochem. Socs Lett. 296, 67-68.

Matozaki T., Sakamoto C., Nagao M. and Baba S. (1987) Protein kinase $\mathrm{C}$ regulates somatostatin binding to its receptors on rat pancreatic acinar cell membranes. Biomed. Res. 8, 39-44.

Moore S. D., Madamba S. G., Joëls M. and Siggins G. R. (1988) Somatostatin augments the M-current in hippocampal neurons. Science 239, 278-280.

Munson P. J. and Rodbard D. (1980) A versatile computerized approach for characterization of ligand binding systems. Anal. Biochem. 107, 220-239.

Pappas S.C., Ferenci P. and Jones E.A. (1984) Hepatic encephalopathy: A disorder of synaptic plasma membrane composition and fluidity? In Advances in hepatic encephalopathy and urea cycle diseases (Kleinberger G., Ferenci P., Rieder P. and Thaler H., Eds), pp. 331-336. Karger, Basel.

Patel J. C. and Reichlin S. (1978) Somatostatin in hypothalamus, extrahypotalamic brain, and peripheral tissues of the rat. Endocrinology 102, 523-531.

Patel S. C., Papachristou D. N. and Patel Y. C. (1991) Quinolinic acid stimulates somatostatin gene expression in cultured rat cortical neurons. J. Neurochem. $\mathbf{5 6 0}, 1286$ 1291.

Pérez J., Rigo M., Kaupmann K., Brunns C., Yasuda K., Bell G. I., Lübbert H. and Hoyer D. (1994) Localization of somatostatin (SRIF) SSTR-1, SSTR-2 and SSTR-3 receptor mRNA in rat brain by in situ hybridization. Naunyn-Schmiedeberg's Arch. Pharmacol. 349, 145-160.

Pitkanen A., Sirvio J., Jolkkonen J. and Reikkinen P. (1986) Somatostatin-like immunoreactivity and somatostatin receptor binding in rat brain before and after pentylenetetrazol induced convulsion. Neuropeptides 7, 63-71.

Pittman Q. J. and Siggins G. R. (1981) Somatostatin hyperpolarizes pyramidal cells in vitro. Brain Res. 221, 402408 .

Prior R. L. and Visek W. J. (1972) Effects of urea hydrolysis on tissue metabolite concentrations in rats. Am.J. Physiol. 223, 1143-1149.

Raabe W. and Lin S. (1985) Pathophysiology of ammonia intoxication. Exp. Neurol. 87, 519-532.

Rage F., Alonso G. and Tapia-Arancibia L. (1993) Stimulatory effect of $N$-methyl-D-aspartate on somatostatin gene expression in cultured hypothalamic neurons. Mol. Brain Res. 17, 287-294.

Reubi J. C. (1984) Evidence for two somatostatin-14 receptor types in rat brain cortex. Neurosci. Lett. 49, 259-263.

Rodríguez-Sánchez M. N., Colás B., Prieto J. C. and Arilla E. (1989) Effects of insulin-induced hypoglycemia on somatostatin level and binding in rat cerebral cortex and hippocampus. Brain Res. 494, 36-41.

Schonbrunn A., Rorstad O. P., Westendorf J. M. and Martin J. B. (1983) Somatostatin analogs: Correlation between receptor binding affinity and biological potency in $\mathrm{GH}$ pituitary. Endocrinology 113, 1559-1567.

Schweitzer P., Madamba S., Champagnat J. and Siggins G. R. (1993) Somatostatin inhibition of hippocampal CA 1 
pyramidal neurons: mediation by arachidonic acid and its metabolites. J. Neurosci. 13, $2033-2049$.

Shulkes A., Caussignac Y. V., Lamers C. B., Solomon T. E.. Yamada T. and Walsh J. H. (1983) Starvation in the rat: effect on peptides of the gut and brain. Australian $J$. Exp. Biol. Med. Sci. 61, 581-587.

Srikant C. B. and Patel Y. C. (1981) Somatostatin receptors: Identification and characterization in rat brain membranes. Proc. Natl. Acad. Sci. USA 78, 3930-3934.

Szerb J. C. and Butterworth R. F. (1992) Effect of ammonium ions on synaptic transmission in the mammalian central nervous system. Progr. Neurobiol. 39, 135 153.

Terry L. C., Epelbaum J. and Martin J. B. (1981) Monosodium glutamate acute and chronic effects on rhythmic growth hormone and prolactin secretion, and somatostatin in the undisturbed male rat. Brain Res. 217, 129 142.

Tran V., Beal F. and Martin J. (1985) Two types of somatostatin receptors differentiated by cyclic somatostatin analogs. Science 228, 492-495.
Twery M. J. and Gallagher J. P. (1989) Somatostatin hyperpolarizes neurons and inhibits spontaneous activity in the rat dorsolateral septal nucleus. Brain Res. 497, 315 . 324.

Wang H. L., Bogen C., Reisine T. and Dichter M. (1989) Somatostatin-14 and somatostatin-28 induce opposite effects on potassium currents in rat neocortical neurons Proc. Natl. Acad. Sci. USA 86, 9616-9620.

Watson T. W. J. and Pittman Q. J. (1988) Pharmacological evidence that somatostatin activates the $\mathrm{M}$-current in hippocampal pyramidal neurons. Neurosci. Lett. 91,172 176.

Yu S. and Ho I. K. (1990) Effects of GABA antagonist. SR9553I and bicuculline on GABA $_{A}$ receptor-regulated chloride flux in rat cortical synaptoneurosomes. Neuruchem. Res. 15, $905-910$.

7.eneroli M. L.. Ventura E., Pinelli G., Casciarri I., Germini M. Cavalletti E., Tofanetti O. and Baraldi M. (1985) Opiate receptors and $B$-endorphin levels in brain areas of dogs with portal-systemic encephalopathy. J. Hepatol. 1, 619627 